\title{
2
}

\section{Persons and Human Capital}

\begin{abstract}
The wellbeing economics framework begins with individual persons seeking to create the kinds of lives they value, and have reason to value. These persons are able to make time-use choices they reason will promote wellbeing, influenced by cultural values, personal abilities and social capabilities. The attention to choices about time-use is because persons have equal time to allocate each day, and because time-use choices influence monetary values recorded in market transactions. Persons can expand capabilities through formal education and through relevant experience, which are time-use choices that economists describe as investment in human capital. Progress in wellbeing can be monitored using measures of subjective and objective wellbeing, exemplified in the Organisation for Economic Co-operation and Development's Better Life Initiative.
\end{abstract}

Keywords Human capital $\bullet$ Wellbeing measures $\bullet$ Time-use choices $\bullet$ Skills $\bullet$ Sustainability

Our analysis begins with an individual person striving to live a valued kind of life. This person is presumed able to exercise relational autonomy, meaning that at key moments in life, we humans expect to be able to make reasoned choices within the context of our own cultural and social environments. This chapter 
pays attention to time-use choices, for two reasons. First, all persons have the same amount of time to spend each day, so that this fundamental equality is a useful starting point for inquiries into persistent inequalities in personal wellbeing over a lifetime. Second, time-use choices influence economic values recorded in the market economy. The first two sections of this chapter explore these aspects of time-use choices.

The chapter then introduces the first of the seven capitals in our wellbeing economics framework. Individuals can improve capabilities for wellbeing through formal education, relevant experience and better health. These are timeuse choices that economists have long described as investment in human capital. The final section before the chapter's brief conclusion explains how a mixture of subjective and objective wellbeing measures can be used to monitor changes in wellbeing levels of a community or country.

\section{Living Life}

Among the many ways for promoting wellbeing, this book focuses on private and public initiatives to expand the capabilities of persons for leading lives they value, and have reason to value. On a day-to-day basis, human lives are constructed by persons, living in communities, making choices about how to spend their time (see also Kahneman et al. 2006, p. 1910). Our approach to these choices is expressed in Proposition 4.

Proposition 4 Persons can make time-use choices they reason will promote wellbeing, influenced by their cultural values, personal abilities and social capabilities.

This introduces concepts prominent throughout this book. First, the focus is on choices about time-use. As Waring (1996, p. 88) observes, "time is the one unit of exchange we all have in equal amounts, the one investment we all have to make" (see also Gershuny 2000; Stiglitz et al. 2009, pp. 126-128 and the Canadian Index of Wellbeing 2012, pp. 49-53). All humans in this respect have the same entitlement each day. Hence, persistent inequality in wellbeing can be explored by researching constraints on the range of time-use choices available to different segments of the population, as well as the different consequences of different time-use choices made by persons. 
Further, time-use choices made at key moments in life can have profound impacts on wellbeing that are qualitatively greater than other types of choices. Examples include the number of years spent in formal education, patterns of behaviour within a household, volunteered commitments to community groups, participation in hours of market employment, and involvement in recreational and cultural activities, all of which have stronger and more enduring impacts on personal wellbeing than, say, choices between different brands of consumption goods.

Second, Proposition 4 states that persons can make choices they reason will promote wellbeing. There are important exceptions (young children lack this capacity, for example, as can people suffering certain illnesses), but at moments of big decisions in a lifetime, persons can expect they will be able to exercise personal agency, in the sense of using their "capacity to deliberate and to act on the basis of reason" (Mackenzie 2007, p. 105). At these moments, choice-making is not a matter of simply applying pre-determined preferences or tastes, but involves reasoned deliberation within a person's cultural and social contexts. This understanding of human agency has been termed relational autonomy (Mackenzie and Stoljar 2000; Stoljar 2015), with the resulting conceptualisation of wellbeing sometimes termed relational wellbeing (White 2015, 2017).

The claims in Proposition 4 are not strong or normative. The proposition does not say, for example, that promotion of wellbeing is the only motivation affecting time-use choices, nor does it say that all choices are, or should be, motivated in this way. There is no presumption that a person's reasoning is correct, immune from external criticism or unable to be influenced by policy nudges that recognise the limits of human cognitive capacities (Thaler and Sunstein 2008; Halpern 2015).

The proposition does not expect universal agreement on what constitutes wellbeing; indeed, this is not possible since wellbeing is influenced by the choicemaker's own cultural values. The values are "cultural" because they are developed within specific cultural settings and because social values are continuously being transformed as part of the wider community's cultural vitality (see Chap. 3).

Finally, Proposition 4 recognises that time-use choices are influenced by personal abilities and by social capabilities. To illustrate the difference, consider a boy and a girl with the same aptitude for learning. If custom or law permits boys to advance to higher education, but not girls, then the two children have equal personal abilities but unequal social capabilities for developing skills. ${ }^{1}$ Similarly, a woman and a man may have equal personal abilities for paid employment in an occupation, but if women are routinely paid less than men in that occupation, then the social capabilities of the two persons are again unequal. ${ }^{2}$ 
Another important example concerns persons who are living with physical impairments compared to social peers. A physical impairment may affect personal abilities, but this is accentuated if accompanied by a loss of social capability (creating social disability; see, e.g., Oliver 1996) when public policy fails to account for the abilities of this population.

Proposition 1 states that economics is to contribute to enhanced wellbeing. The language is deliberate. Since persons are able to make reasoned time-use choices, policy advisors must engage with what persons are already doing to enhance the wellbeing of themselves, their families, their households and their communities, before designing policies that might build on those efforts to allow greater wellbeing to be achieved.

\section{Time-Use Choices and Market Values}

To introduce links between time-use choices and market values, consider the time-use choice made by some persons to participate in sport. Sport England (2013) estimates that in the year ending 14 October 2012, 7.4 million adults in England engaged in at least 30 minutes of moderate intensity sport three times a week. Another 8.1 million did so weekly, and a further 5.5 million did so monthly. This was a substantial investment of time, amounting to more than 820.8 million hours in total over the year.

This is a practical example of persons making time-use choices as part of a kind of life they value. These choices are clearly influenced by cultural values, personal abilities and social capabilities, dependent on sporting associations catering for diverse interests and skills. The participants can reasonably expect this time-use choice to promote wellbeing, since the benefits of physical activity for good physical and mental health are well documented (see, e.g., Government Office for Science 2008; World Health Organization 2010; Institute of Medicine 2013).

This activity also requires significant amount of market transactions, including purchases of specialist goods and services such as sports clothing, sports equipment, club membership fees, facility fees, medical expenses and travel costs. Sport England (2013) reports that spending for active participation in sport contributed an estimated $£ 11.8$ billion to the English economy in 2010, which was 1.1 per cent of the country's gross value added that year. ${ }^{3}$

A great deal of attention is paid to the value of market purchases such as these, but note that the market value exists only because people have made 
time-use choices (in this case, to participate in sport). Without the time-use choices, there would be no demand to purchase sports equipment or to pay club membership fees, and hence no opportunity for the suppliers of sports goods and services to create market value.

The time allocated to sport has a cost, since it represents time that cannot be spent in other valued activities (see Gratton and Taylor 2000, pp. 50-51). The sacrifice is called the opportunity cost of time (Shaw 1992). Becker (1965) demonstrated how to measure this cost, by estimating the income that might have been earned if the time had been spent in market employment. The idea is that paid work is an alternative time-use choice. Thus, if the 820.8 million hours of participation in active sport had been spent in employment at the statutory adult minimum wage (which was $£ 6.08$ in October 2011), this would have created an income of $£ 5.0$ billion. That sacrificed income is a measure of the opportunity cost of participation in active sport. ${ }^{4}$

These ideas mean economists can estimate how much value participants obtain from active sports. It is reasonable to presume that participation creates value that outweighs all associated costs; otherwise, a person would choose an alternative activity that is more highly valued (Samuelson 1938, 1948). Thus, the personal value of active sport participation in England must have been at least $£ 17$ billion in 2011-2012 to cover $£ 12$ billion spent in the market economy on goods and services for sport participation and $£ 5$ billion to compensate for the opportunity cost of the participants' time.

The spending on market goods and services creates another connection between time-use choices and market values, since the income needed to finance these purchases comes through market employment. ${ }^{5}$ Hence, a time-use choice to participate in sport is connected to a person's time-use choice to participate in paid work. This leads to the obvious point that the wage or salary that a person is capable of earning through an hour of paid employment is a crucial element of wellbeing, as will be analysed further in Chap. 5.

Figure 2.1 generalises from this example to highlight connections among wellbeing values, market values and time-use choices. The column on the right depicts the time allocated to earning market income to pay for the market goods and services needed for the valued activities (shown as the horizontal arrow to the lighter-shaded area of the left column). The darker shaded area of the left column shows time allocated to the valued activities themselves, using the purchased goods and services (shown as the vertical arrow). The personal wellbeing created from these choices is the value created by the person's time engaged in the valued activities (presumed to be greater than his or her opportunity cost of 


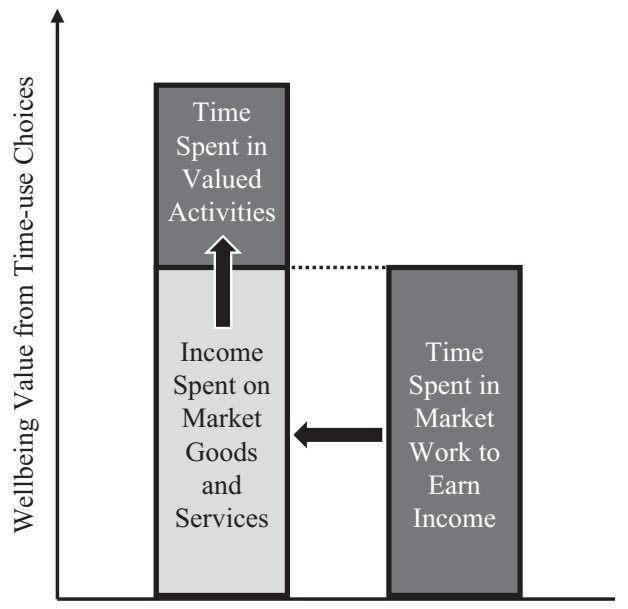

Time-use Choices

Fig. 2.1 The wellbeing value from time-use choices

time) plus the value of the person's time spent earning the income need to purchase the relevant goods and services.

In summary, personal wellbeing and market values are both built on time-use choices. These choices take place within social and cultural contexts and are therefore influenced by personal abilities and social capabilities. Given Propositions 1 and 2, the analysis must explain how individual and collaborative actions can expand capabilities. Proposition 3 draws attention to capital investment and so the following section introduces the first of the seven capitals considered in this book-human capital.

\section{Human Capital}

The term human capital to describe expanded capabilities through formal education, or through relevant experience, has been prominent in economics since its introduction by Mincer (1958), Shultz (1960, 1961) and Becker (1962, 1964); see, for example, reviews by Harmon et al. (2003), Sianesi and Van Reenen (2003) and Tobias and Li (2004). Education generates a range of personal and social benefits, including a reasonable expectation that greater skills will increase a person's labour productivity. An employee with more education, 
or with greater experience, can produce a greater value of output per hour of work compared to employees with basic skills only. This is analogous to how a greater amount of physical capital (a tractor rather than a spade, for example) can increase productivity. Because skills are embodied in persons-in contrast to the spade or tractor-this concept is called human capital.

Like physical capital, human capital requires sacrifices of current consumption in return for the prospect of future rewards. Consider a student choosing from two options: (1) enrolling for a further year of education; and (2) leaving formal education to accept paid employment. Option 1 means sacrificing income that could be earned in option 2, but new skills learned in the first option will result in higher income in future employment. Economic reasoning therefore advises the student to remain in education for as long as expected increases in future income are sufficiently high to compensate for sacrificed current income.

The purpose of education and experience is to develop skills. The Organisation for Economic Co-operation and Development (OECD) describes skills as "the global currency of the 21st century", warning that "without proper investment in skills, people languish on the margins of society, technological progress does not translate into economic growth, and countries can no longer compete in an increasingly knowledge-based global society" (OECD 2012, p. 3). In a wellbeing economics framework, this idea applies to skills that contribute to any aspect of wellbeing (such as cultural vitality, as well as economic wellbeing).

Since skills are embodied in persons, education begins with the individual learner (Cornelius-White 2007), who must be provided with opportunities to discover personal abilities, an idea going back at least to Rousseau (1762). The important role of self-discovery through education has been incorporated in economic models of human capital investment; see, for example, Altonji (1993), Weiler (1994) and Arcidiacono (2004). As Manski (1989) argues, an implication is that failure in education is not always a poor outcome, since it may be a necessary part of discovering genuine interests and abilities. Indeed, a society that encourages creativity and innovation should support learners to try new activities and explore potential skills.

Education then allows learners to discipline their discovered abilities through study and practice, which may be certified through qualifications trusted by potential employers or clients (Spence 1973; Riley 2001). These disciplined abilities may then be displayed as personal skills when the learner uses them to contribute to wellbeing, perhaps through employment, but also in any dimension of human flourishing (see Fig. 2.2). 


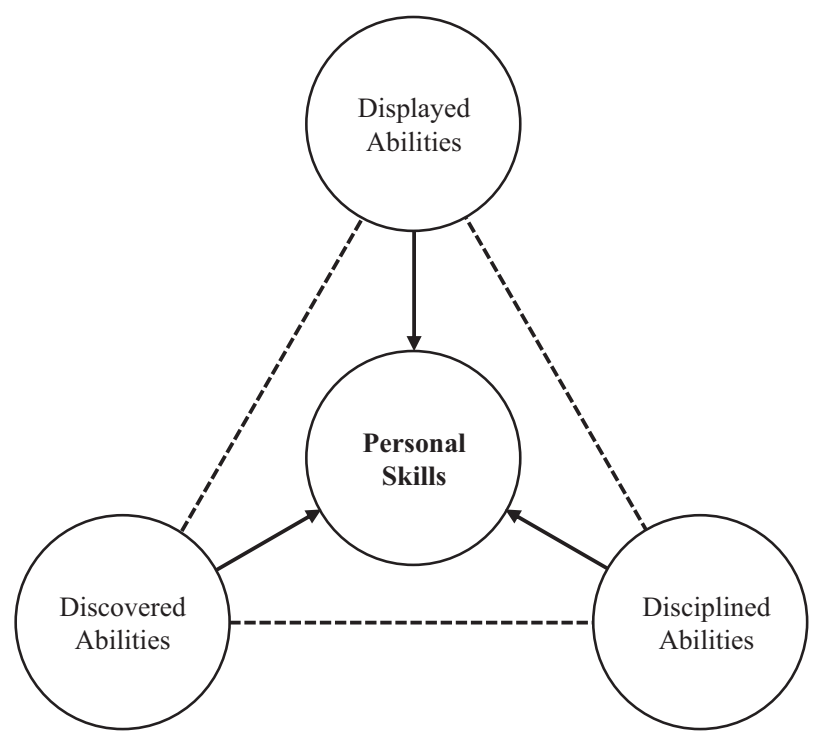

Fig. 2.2 Personal skills as the integration of discovered, disciplined and displayed abilities. (Source: Adapted from Dalziel $(2015,2017)$ )

Recall from Fig. 2.1 that adult lives are constructed around time spent in market work and time spent in other chosen activities. Both types of time-use choice can be expanded when a person has higher levels of relevant skills. Beginning with time spent in employment, there is strong evidence that education offers high market returns. Harmon et al. (2003) reviewed more than a thousand studies of the financial rewards to persons undertaking a further year of schooling. They found consistent reports of a return of around 6.5 per cent, which is well above the recommended return of 3.5 per cent for public sector investment projects in the United Kingdom (HM Treasury 2011, p. 26). Consequently, it is almost universal for government policy to aim for greater levels of human capital investment across the whole population (Buchanan et al. 2017).

As well as opening up the possibility of higher market incomes, higher skills across a range of recreational and cultural activities can expand the capabilities of persons to create lives they have reason to value. An education system with an exclusive focus on market-oriented skills would therefore result in impoverished lives if students do not have opportunities to discover, discipline and display other important life-skills (see, e.g., Connell 2000).

The discussion of this section is summarised in Proposition 5. 
Proposition 5 Investment in human capital through education can provide persons, in all their diversity, with opportunities to discover, discipline and display skills that contribute to wellbeing.

\section{Monitoring Wellbeing}

Proposition 1 states that the primary purpose of economics is to contribute to enhanced wellbeing of persons. This section therefore examines how trends in personal wellbeing can be monitored, beginning with self-evaluations by persons of their own sense of wellbeing. Indicators based on self-assessments are termed measures of subjective wellbeing (Veenhoven 1996; Frey and Stutzer 2002; Peasgood 2008; Blanchflower and Oswald 2011). Indicators of this type are constructed from population surveys that ask participants to assess their wellbeing on a numerical scale, perhaps from zero to ten.

The question can be posed in different ways to focus on diverse aspects of subjective wellbeing, as shown in Table 2.1 (Dolan et al. 2011; see also Cabinet Office 2016, Fig. 17, p. 10). The first way invites participants to rate their current state of mind, both positively (their level of happiness) and negatively (their level of anxiety). These are typically asked as separate questions and result in experience measures of subjective wellbeing. The second type of question asks people to rate their life satisfaction, producing evaluation measures. The third approach requests participants to rate the extent to which they feel that what they do is worthwhile, resulting in a eudemonic measure of subjective wellbeing (see also Bruni 2010). The word comes from Aristotle's vision of eudemonia as living well, consistent with the objective of "human flourishing" emphasised by Tim Jackson (2017) and others. It is the measure emphasised in Sen's capabilities approach and reflected in our Proposition 2.

Survey questions such as those in Table 2.1 can be used to identify groups with lower self-assessed wellbeing than the general population (Krueger and Schkade 2008). An authoritative review by Dolan et al. (2008), for example, suggests that poor health, marital separation, unemployment and lack of social contact are strongly associated with low levels of subjective wellbeing (see also Helliwell and Putnam 2002). That review cautioned against drawing firm conclusions about causes of wellbeing until more data are available, and there are other concerns about whether self-assessed measures are sufficient for monitoring wellbeing. Amartya Sen $(1987$, p. 8), for example, has offered the following hypothetical case to illustrate a deeper problem: 
Table 2.1 Examples of survey questions to elicit three different types of subjective assessments of wellbeing

\begin{tabular}{ll}
\hline Assessment Type & Example of Survey Question \\
\hline Experience & Overall, on a rising scale from 0 to 10, how happy did you feel \\
& yesterday? \\
& Overall, on a rising scale from 0 to 10 , how anxious did you feel \\
& yesterday? \\
Everall, on a rising scale from 0 to 10 , how satisfied are you with \\
your life nowadays? \\
Eudemonic & Overall, on a rising scale from 0 to 10, to what extent do you feel \\
& that the things you do in your life are worthwhile?
\end{tabular}

Source: Adapted from Dolan et al. (2011, Table 1, p. 14)

Consider a very deprived person who is poor, exploited, overworked and ill, but who has been made satisfied with his lot by social conditioning (through, say, religion, political propaganda, or cultural pressure). Can we possibly believe that he is doing well just because he is happy and satisfied?

Consider also the limitations on social opportunities of women compared to men in most societies (Boserup 1970; Nussbaum and Glover 1995; Nussbaum 2001; Mackenzie 2007; Khader 2011). Betty Friedan, for example, analysed the post-war ideology that pressured women in the United States, and elsewhere, to accept "their own nature, which can find fulfilment only in sexual passivity, male domination, and nurturing maternal love" so that "lives were confined, by necessity, to cooking, cleaning, washing, bearing children" (Friedan 1963, p. 38). ${ }^{6}$ The feminine mystique was widely accepted following World War II, but reason meant it had to be rejected: "Self-esteem in woman, as well as in man, can only be based on real capacity, competence, and achievement" (idem, p. 273).

The phenomenon of individual expectations adjusting to social experience is termed adaptive preferences (Nussbaum 2001). It is not unusual; indeed, Wilson and Gilbert (2003, p. 401) comment that "people are consummate sense makers who transform novel, emotion-producing events into ones that seem ordinary and mundane, through the processes of assimilation, accommodation, and explanation". Examples include Easterlin's (2001, p. 481) conclusion that over a person's life cycle, income growth does not cause reported happiness to rise "because it generates equivalent growth in material aspirations, and the negative effect of the latter on subjective well-being undercuts the positive effect of the former". Graham (2008, p. 79) observes a similar effect in the relationship between health and happiness: "people no doubt adapt to better health conditions and, in turn, expect them”. 
Aspirations may also rest on ill-informed or limited knowledge (Somin 2004; Schnellenbach 2008). This is a wider policy issue than the measure of subjective wellbeing, but its relevance can be illustrated with the finding from the British Household Panel Survey that the level of environmental awareness affects a person's subjective wellbeing (Ferrer-i-Carbonell and Gowdy 2007). Thus, widespread underestimation of realistic climate change threats could result in inflated measures of subjective wellbeing compared to a situation where all survey participants understood the scientific consensus presented in authoritative documents such as IPCC (2015).

Consequently, indicators of subjective wellbeing are not sufficient for monitoring purposes. Recall from Proposition 2 that wellbeing can be enhanced by expanding the capabilities of persons to lead the kinds of lives they value and have reason to value. Thus, relevant influences on personal wellbeing (such as quality of available housing, levels of material living standards and state of the natural environment) can be identified and then monitored (Tomlinson and Kelly 2013; Scott 2015). Because they rely on externally observable data, these indicators are termed measures of objective wellbeing.

There is an important debate in the literature about how the influences on wellbeing should be identified (Nussbaum 2003; Sen 2004). Sen argues that the process should be undertaken by members of each community exercising their own agency, since outsiders should not presume to impose their own choices on a community (Sen 1999, p. 11):

...with adequate social opportunities, individuals can effectively shape their own destiny and help each other. They need not be seen primarily as passive recipients of the benefits of cunning development programs. There is indeed a strong rationale for recognising the positive role of free and sustainable agency.

Nussbaum (2003) observes that adequate social opportunities are not universally available, and so Sen's opening proviso is not always realised. Nussbaum argues that a list of "central human capabilities" can be designed to reflect the fundamental dignity of the human person, while being sensitive to cultural difference and open to change. It can record essential entitlements for social justice, overlapping with the human rights literature (see also Nussbaum 1997). Nussbaum proposes an initial set of central capabilities, organised under ten themes (Nussbaum 2003, pp. 41-42; 2011, pp. 33-34):

1. Life

2. Bodily health 
3. Bodily integrity

4. Senses, imagination and thought

5. Emotions

6. Practical reason

7. Affiliation

8. Other species

9. Play

10. Control over one's environment

Measures of subjective and objective wellbeing can be combined in a suite of indicators. An exemplar is the OECD's Better Life Initiative (OECD 2011, $2013,2015 ; 2017)$, which has created the conceptual framework reproduced in Fig. 2.3.

The OECD framework has three domains. The first, material conditions, covers three headings: income and wealth; jobs and earning; and housing. Gross domestic product (GDP) is recognised as contributing to these material conditions, but is

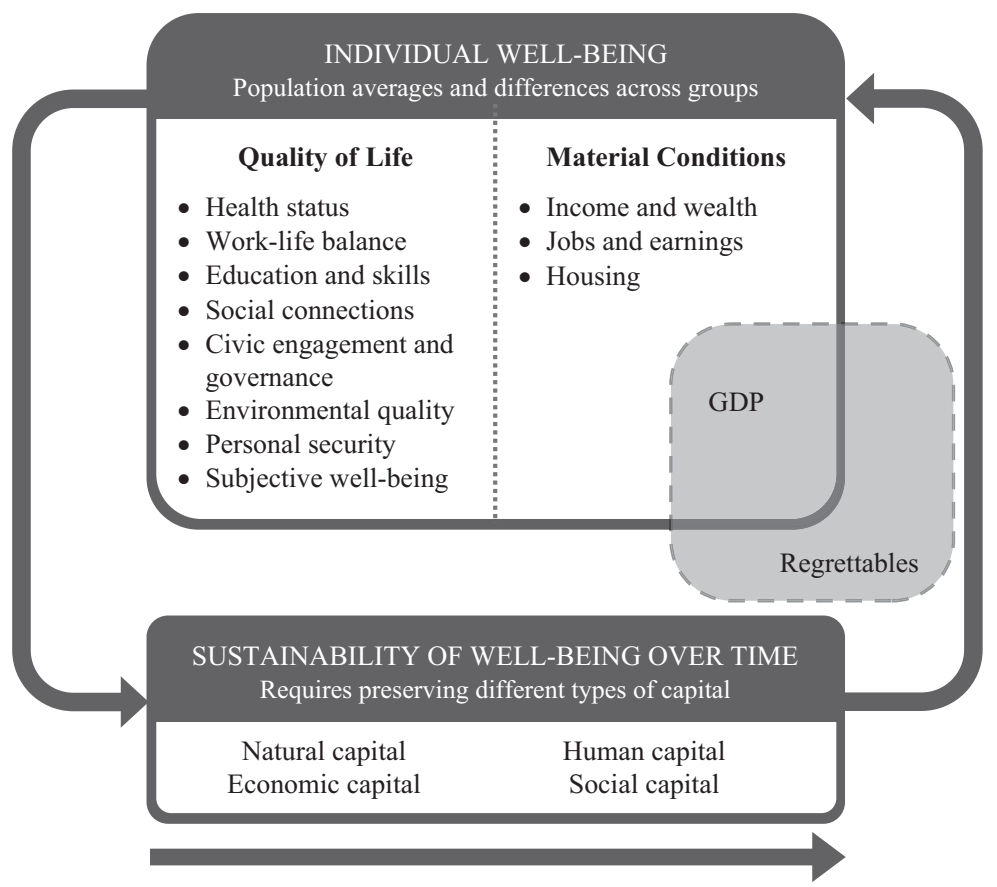

Fig. 2.3 The OECD wellbeing conceptual framework. (Source: OECD (2013, Fig. 1.2, p. 21)) 
also associated with certain "regrettables" (such as damage to the natural environment) that detract from wellbeing. ${ }^{8}$

The second domain, quality of life, records other relevant measures. It includes seven groups of objective wellbeing indicators: health status; work-life balance; education and skills; social connections; civic engagement and governance; environmental quality; and personal security. An eighth set incorporates indicators of subjective wellbeing into the framework.

The third domain is sustainability. It draws attention to the preservation of four different types of capital stock: natural capital; human capital; economic capital and social capital. This recognises that wellbeing is likely to fall if the services provided by these assets decline over time, which is consistent with the capitals approach taken in this book. ${ }^{?}$

In this context of services provided by different types of capital stock, there is an important debate in the literature about strong sustainability versus weak sustainability (see, e.g., Hediger 2006). The issue is whether the economic system can be described as sustainable if the stock of one capital type is declining over time (especially reduced natural capital as a result of resource extraction or environmental degradation) but stocks of other capital types (such as economic or human capital) are increasing.

Proponents of weak sustainability argue that it is possible for investment in economic and human capital to compensate for degraded natural capital. Consequently, economists are attempting to measure comprehensive wealth for countries, defined as the aggregated value of all capital stocks measured at prices reflecting the marginal contribution of each capital type to wellbeing (see, e.g., World Bank 2011; Arrow et al. 2012; Hanley et al. 2015). The system is said to be sustainable if comprehensive wealth on a per capita basis does not decline over time, even if natural capital deteriorates.

Proponents of strong sustainability argue instead that at least some aspects of natural capital are not substitutable by other types of capital, especially once degradation moves beyond certain limits. This is the approach taken by Jackson (2017) discussed in Chap. 1. It also underlies the finding of the Stern Review in the United Kingdom that "climate change will have serious impacts on world output, on human life and on the environment" (Stern 2007, p. $\mathrm{xvi}$ ). In this approach, the system is not sustainable unless key aspects of natural capital are preserved. Chapter 6 will return to this debate, but this section finishes by recording the feasibility of monitoring personal wellbeing trends. 
Proposition 6 Personal wellbeing can be monitored using a set of indicators that include measures of subjective and objective wellbeing, supplemented by measured trends in different types of capital.

\section{Conclusion}

This chapter has introduced individual persons seeking to create lives they value, and have reason to value. These persons are able to make time-use choices they reason will promote wellbeing, influenced by their own cultural values, personal abilities and social capabilities. These time-use choices influence monetary values recorded in market transactions.

Because the choices are influenced by social capabilities, the wellbeing economics framework explores how capabilities can be expanded. An important example is education that helps learners in all their diversity to discover, discipline and display their full range of abilities. This is termed investment in human capital. The final section of the chapter finished with the OECD's wellbeing conceptual framework, presented as an exemplar of how to monitor trends across a range of personal wellbeing indicators.

The following chapter turns to how collaborative actions among different persons can enhance wellbeing, focusing in the first instance on the choices made by persons living in households and families.

\section{Notes}

1. Duflo (2012) summarises evidence for the benefits of a policy commitment to equality in the education of children, both for its own sake and as a contribution to stronger economic development. See also Nussbaum (2000).

2. In the United States, an Equal Pay Act prohibiting this form of discrimination was passed only in 1963, and not until 1970 in the United Kingdom. Nevertheless, female-male wage gaps remain in these and other countries (National Equal Pay Task Force 2013; Rubery and Grimshaw 2015; European Union 2014).

3. Gross value added is the difference between the value of a sector's output and the value of goods and services purchased from other sectors as inputs into production. It is the core measure used in calculating a country's GDP. Of course, if the participants' income had not been spent on these goods and services, it could have been spent elsewhere; hence, this analysis is not claiming that the economy would have been smaller without this participation in sport. 
4. Only people aged 21 and over are entitled to the statutory adult minimum wage, but this overestimate is more than offset by: not considering that most adults can earn more than the living wage; using the minimum 30 minutes as the time spent in each session of sport; and not including the opportunity cost of volunteered hours in the sector.

5. The analysis is made more complicated, but not fundamentally changed, if it incorporates the possibility of some earned income being saved for investment in financial assets that then generate future income for the saver.

6. Folbre and Hartmann (1988) and Folbre and Nelson (2000) analysed similar gender dualisms in the economics literature.

7. Easterlin's theory is not universally accepted; see Stevenson and Wolfers (2008) and the review by Clark et al. (2008). Wilkinson and Pickett (2009) hypothesise that expectations adapting to social relativities is a major mechanism through which greater inequality in a society diminishes wellbeing, by making people anxious about not being able to achieve, or maintain, a kind of life that is judged reasonable by their peers.

8. This feature of the figure has been removed in later publications; see, for example, $\operatorname{OECD}$ (2015, Fig. 1.1, p. 23).

9. This book's wellbeing economics framework expands the list of capital to include cultural capital, knowledge capital and diplomatic capital. These additional capitals are not currently as easily measured as the four highlighted by the OECD, but later chapters argue that their services are essential for wellbeing.

\section{References}

Altonji, Joseph G. 1993. The Demand for and Return to Education When Education Outcomes Are Uncertain. Journal of Labor Economics 11 (1): 48-83.

Arcidiacono, Peter. 2004. Ability Sorting and the Returns to College Major. Journal of Econometrics 121 (1-2): 343-375.

Arrow, Kenneth J., Partha Dasgupta, Lawrence H. Goulder, Kevin J. Mumford, and Kirsten Oleson. 2012. Sustainability and the Measurement of Wealth. Environment and Development Economics 17 (3): 317-353.

Becker, Gary. 1962. Investment in Human Capital: A Theoretical Analysis. Journal of Political Economy 70 (5, Part 2): 9-49.

- 1964. Human Capital: A Theoretical and Empirical Analysis, with Special Reference to Education. New York: Columbia University Press.

- 1965. A Theory of the Allocation of Time. Economic Journal75 (299): 493-517.

Blanchflower, David G., and Andrew J. Oswald. 2011. International Happiness: A New View on the Measure of Performance. Academy of Management Perspectives 25 (1): 6-22. 
Boserup, Ester. 1970. Woman's Role in Economic Development. New York: St. Martin's Press.

Bruni, Luigino. 2010. The Happiness of Sociality. Economics and Eudaimonia: A Necessary Encounter. Rationality and Society 22 (4): 383-406.

Buchanan, John, David Finegold, Ken Mayhew, and Chris Warhurst, eds. 2017. The Oxford Handbook of Skills and Training. Oxford: Oxford University Press.

Cabinet Office. 2016. Community Life Survey 2015-16 Statistical Bulletin. London: Cabinet Office Official Statistics.

Canadian Index of Wellbeing. 2012. How are Canadians Really Doing? The 2012 CIW Report. Waterloo, ON: Canadian Index of Wellbeing and University of Waterloo.

Clark, Andrew E., Paul Frijters, and Michael A. Shields. 2008. Relative Income, Happiness, and Utility: An Explanation for the Easterlin Paradox and Other Puzzles. Journal of Economic Literature 46 (1): 95-144.

Connell, Jeanne M. 2000. Aesthetic Experiences in the School Curriculum: Assessing the Value of Rosenblatt's Transactional Theory. Journal of Aesthetic Education 34 (1): 27-35.

Cornelius-White, Jeffrey. 2007. Learner-centered Teacher-Student Relationships are Effective: A Meta-analysis. Review of Educational Research 77 (1): 113-143.

Dalziel, Paul. 2015. Regional Skill Ecosystems to Assist Young People Making Education Employment Linkages in Transition from School to Work. Local Economy 30 (1): 53-66.

. 2017. Education and Qualifications as Skills. In The Oxford Handbook of Skills and Training, ed. John Buchanan, David Finegold, Ken Mayhew, and Chris Warhurst, 143-160. Oxford: Oxford University Press.

Dolan, Paul, Tessa Peasgood, and Mathew White. 2008. Do We Really Know What Makes Us Happy? A Review of the Economic Literature on the Factors Associated with Subjective Well-being. Journal of Economic Psychology 29 (1): 94-122.

Dolan, Paul, Richard Layard and Robert Metcalfe. 2011. Measuring Subjective Wellbeing for Public Policy: Recommendations on Measures. Special Paper No. 23, Centre for Economic Performance, London School of Economics. Retrieved September 20, 2016, from http://eprints.lse.ac.uk/47518/1/CEPSP23.pdf.

Duflo, Esther. 2012. Women Empowerment and Economic Development. Journal of Economic Literature 50 (4): 1051-1079.

Easterlin, Richard A. 2001. Income and Happiness: Towards a Unified Theory. Economic Journal 111 (July): 465-484.

European Union. 2014. Tackling the Gender Pay Gap in the European Union. Luxembourg: Publications Office of the European Union.

Ferrer-i-Carbonell, Ada, and John M. Gowdy. 2007. Environmental Degradation and Happiness. Ecological Economics 60: 509-516.

Folbre, Nancy, and Heidi Hartmann. 1988. The Rhetoric of Self-interest: Ideology and Gender in Economic Theory. In The Consequences of Economic Rhetoric, ed. Arjo 
Klamer, Deirdre N. McCloskey, and Robert M. Solow, 184-203. Cambridge: Cambridge University Press.

Folbre, Nancy, and Julie A. Nelson. 2000. For Love or Money-Or Both? Journal of Economic Perspectives 14 (4): 123-140.

Frey, Bruno S., and Alois Stutzer. 2002. What Can Economists Learn from Happiness Research. Journal of Economic Literature 40 (2): 402-435.

Friedan, Betty. 1963. The Feminine Mystique. New York: W.W. Norton. Citations are from the Penguin edition. Harmondsworth: Penguin, 1965.

Gershuny, Jonathan. 2000. Changing Times: Work and Leisure in Postindustrial Society. Oxford: Oxford University Press.

Government Office for Science. 2008. Mental Capital and Wellbeing: Making the Most of Ourselves in the 21st Century. Foresight Mental Capital and Wellbeing Project, Final Project Report. London: Government Office for Science.

Graham, Carol. 2008. Happiness and Health: Lessons - and Questions - for Public Policy. Health Affairs 27 (1): 72-87.

Gratton, Chris, and Peter Taylor. 2000. Economics of Sport and Recreation. London: Spon Press.

Halpern, David. 2015. Inside the Nudge Unit: How Small Changes Can Make a Big Difference. London: WH Allen.

Hanley, Nick, Louis Dupuy, and Eoin McLaughlin. 2015. Genuine Savings and Sustainability. Journal of Economic Surveys 29 (4): 779-806.

Harmon, Colm, Hessel Oosterbeek, and Ian Walker. 2003. The Returns to Education: Microeconomics. Journal of Economic Surveys 17 (2): 115-155.

Hediger, Werner. 2006. Weak and Strong Sustainability, Environmental Conservation and Economic Growth. Natural Resource Modelling 19 (3): 359-394.

Helliwell, John F., and Robert D. Putnam. 2002. The Social Context of Well-being. Philosophical Transactions - Royal Society of London Series B Biological Sciences 359: 1435-1446.

HM Treasury. 2011. The Green Book: Appraisal and Evaluation in Central Government. London: The Stationery Office.

Institute of Medicine. 2013. Educating the Student Body: Taking Physical Activity and Physical Education to School, ed. Harold W. Kohl III and Heather D. Cook. Washington, DC: National Academies Press.

IPCC. 2015. Climate Change 2014: Synthesis Report. Contribution of Working Groups I, II and III to the Fifth Assessment Report of the Intergovernmental Panel on Climate Change. Geneva: Intergovernmental Panel on Climate Change.

Jackson, Tim. 2017. Prosperity without Growth: Foundations for the Economy of Tomorrow. 2nd ed. Abingdon/New York: Routledge.

Kahneman, Daniel, Alan B. Krueger, David Schkade, Norbert Schwarz, and Arthur A. Stone. 2006. Would You Be Happier If You Were Richer? A Focusing Illusion. Science 312 (5782): 1908-1910. 
Khader, Serene J. 2011. Adaptive Preferences and Women's Empowerment. Oxford: Oxford University Press.

Krueger, Alan B., and David A. Schkade. 2008. The Reliability of Subjective Well-being Measures. Journal of Public Economics 92 (8-9): 1833-1845.

Mackenzie, Catriona. 2007. Relational Autonomy, Sexual Justice and Cultural Pluralism. In Sexual Justice/Cultural Justice: Critical Perspectives on Political Theory and Practice, ed. Barbara Arneil, Monique Deveaux, Rita Dhamoon, and Avigail Eisenberg, 103-121. London/New York: Routledge.

Mackenzie, Catriona, and Natalie Stoljar, eds. 2000. Relational Autonomy: Feminist Perspectives on Autonomy, Agency, and the Social Self. New York/Oxford: Oxford University Press.

Manski, Charles F. 1989. Schooling as Experimentation: A Reappraisal of the Postsecondary Dropout Phenomenon. Economics of Education Review 8 (4): 305-312. Mincer, Jacob. 1958. Investment in Human Capital and Personal Income Distribution. Journal of Political Economy 66 (4): 281-302.

National Equal Pay Task Force. 2013. Fifty Years after the Equal Pay Act. Washington, DC: The White House.

Nussbaum, Martha C. 1997. Capabilities and Human Rights. Fordham Law Review 66 (2): 273-300.

. 2000. Women and Human Development: The Capabilities Approach. Cambridge: Cambridge University Press.

- 2001. Symposium on Amartya Sen's Philosophy: 5 Adaptive Preferences and Women's Options. Economics \& Philosophy 17 (1): 67-88.

- 2003. Capabilities as Fundamental Entitlements: Sen and Social Justice. Feminist Economics 9 (2-3): 33-59.

- 2011. Creating Capabilities: The Human Development Approach. Cambridge, MA: Belknap Press.

Nussbaum, Martha, and Jonathan Glover, eds. 1995. Women, Culture and Development: A Study of Human Capabilities. Oxford: Clarendon Press.

OECD. 2011. How's Life? Measuring Well-being. Paris: OECD Publishing https://doi. org/10.1787/9789264121164-en.

- 2012. Better Skills, Better Jobs, Better Lives: A Strategic Approach to Skills Policies. Paris: OECD Publishing https://doi.org/10.1787/9789264177338-en.

- 2013. How's Life? 2013: Measuring Well-being. Paris: OECD Publishing https:// doi.org/10.1787/9789264201392-en.

- 2015. How's Life? 2015: Measuring Well-being. Paris: OECD Publishing https:// doi.org/10.1787/how_life-2015-en.

- 2017. How's Life? 2017: Measuring Well-being. Paris: OECD Publishing https:// doi.org/10.1787/how_life-2017-en.

Oliver, Michael. 1996. Understanding Disability: From Theory to Practice. New York: St. Martin's Press. 
Peasgood, Tessa. 2008. Measuring Well-Being for Public Policy. Unpublished Ph.D. Thesis, Imperial College London. http://hdl.handle.net/10044/1/5475. Accessed 3 Jan 2016 Riley, John G. 2001. Silver Signals: Twenty-Five Years of Screening and Signaling. Journal of Economic Literature 39 (2): 432-478.

Rousseau, Jean-Jacques. 1762. Émile, or On Education. Translated and annotated by Allan Bloom. Harmondsworth: Penguin, 1979.

Rubery, Jill, and Damian Grimshaw. 2015. The 40-year Pursuit of Equal Pay: A Case of Constantly Moving Goalposts. Cambridge Journal of Economics 39 (2): 319-343.

Samuelson, Paul A. 1938. A Note on the Pure Theory of Consumer's Behavior. Economica 5 (17): 61-71.

. 1948. Consumption Theory in Terms of Revealed Preference. Economica 15 (60): 243-253.

Schnellenbach, Jan. 2008. Rational Ignorance is Not Bliss: When do Lazy Voters Learn from Decentralised Policy Experiments? Jahrbücher für Nationalökonomie und Statistik 228 (4): 372-393.

Scott, Karen. 2015. Happiness on Your Doorstep: Disputing the Boundaries of Wellbeing and Localism. Geographical Journal 181 (2): 129-137.

Sen, Amartya. 1987. The Standard of Living. The Tanner Lectures, Clare Hall, Cambridge, 1985, ed. Geoffrey Hawthorn. Cambridge: Cambridge University Press.

- 1999. Development as Freedom. Oxford: Oxford University Press.

- 2004. Capabilities, Lists, and Public Reason: Continuing the Conversation. Feminist Economics 10 (3): 77-80.

Shaw, W. Douglass. 1992. Searching for the Opportunity Cost of an Individual's Time. Land Economics 68 (1): 107-115.

Shultz, Theodore W. 1960. Capital Formation by Education. Journal of Political Economy 68 (6): 571-583.

- 1961. Investment in Human Capital. American Economic Review 51 (1): 1-17. Sianesi, Barbara, and John Van Reenen. 2003. The Returns to Education: Macroeconomics. Journal of Economic Surveys 17 (2): 157-200.

Somin, Ilya. 2004. When Ignorance Isn't Bliss: How Political Ignorance Threatens Democracy. Policy Analysis No. 525. https://object.cato.org/sites/cato.org/files/pubs/ pdf/pa525.pdf. Accessed 4 Jan 2016.

Spence, Michael. 1973. Job Market Signaling. Quarterly Journal of Economics 87 (3): 355-374.

Sport England. 2013. Economic Value of Sport in England. London: Sport England.

Stern, Nicholas. 2007. The Economics of Climate Change: The Stern Review. Cambridge: Cambridge University Press.

Stevenson, Betsey, and Justin Wolfers. 2008. Economic Growth and Subjective WellBeing: Reassessing the Easterlin Paradox. Brookings Papers on Economic Activity 2008 (Spring): 1-87.

Stiglitz, Joseph, Amartya Sen, and Jean-Paul Fitoussi. 2009. Report by the Commission on the Measurement of Economic Performance and Social Progress. https://www.insee.fr/ en/information/2662494. Accessed 16 July 2017. 
Stoljar, Natalie. 2015. Feminist Perspectives on Autonomy. In The Stanford Encyclopedia of Philosophy. Fall 2015 ed., ed. Edward N. Zalta. https://plato.stanford.edu/archives/ fall2015/entries/feminism-autonomy/. Accessed 2 Jan 2016.

Thaler, Richard H., and Cass R. Sunstein. 2008. Nudge: Improving Decisions about Health, Wealth, and Happiness. New Haven: Yale University Press.

Tobias, Justin L., and Mingliang Li. 2004. Returns to Schooling and Bayesian Model Averaging: A Union of Two Literatures. Journal of Economic Surveys 18 (2): 153-180. Tomlinson, Michael W., and Grace P. Kelly. 2013. Is Everybody Happy? The Politics and Measurement of National Wellbeing. Policy \& Politics 41 (2): 139-157.

Veenhoven, Ruut. 1996. Developments in Satisfaction-Research. Social Indicators Research 37 (1): 1-46.

Waring, Marilyn. 1996. Three Masquerades: Essays on Equality, Work and Human Rights. Auckland: Auckland University Press with Bridget Williams Books.

Weiler, William C. 1994. Expectations, Undergraduate Debt and the Decision to Attend Graduate School: A Simultaneous Model of Student Choice. Economics of Education Review 13 (1): 29-41.

White, Sarah C. 2015. Introduction. The Many Faces of Wellbeing. In Cultures of Wellbeing: Method, Place, Policy, ed. Sarah C. White and Chloe Blackmore, 1-44. Basingstoke: Palgrave Macmillan.

. 2017. Relational Wellbeing: Re-centring the Politics of Happiness, Policy and the Self. Policy \& Politics 45 (2): 121-136.

Wilkinson, Richard G., and Kate Pickett. 2009. The Spirit Level: Why More Equal Societies Almost Always Do Better. London: Allen Lane.

Wilson, Timothy D., and Daniel T. Gilbert. 2003. Affective Forecasting. Advances in Experimental Social Psychology 35: 345-411.

World Bank. 2011. The Changing Wealth of Nations: Measuring Sustainable Development in the New Millennium. Washington, DC: World Bank Group.

World Health Organization. 2010. Global Recommendations on Physical Activity for Health. Geneva: World Health Organization Press. 
Open Access This chapter is licensed under the terms of the Creative Commons Attribution 4.0 International License (http://creativecommons.org/licenses/by/4.0/), which permits use, sharing, adaptation, distribution and reproduction in any medium or format, as long as you give appropriate credit to the original author(s) and the source, provide a link to the Creative Commons license and indicate if changes were made.

The images or other third party material in this chapter are included in the chapter's Creative Commons license, unless indicated otherwise in a credit line to the material. If material is not included in the chapter's Creative Commons license and your intended use is not permitted by statutory regulation or exceeds the permitted use, you will need to obtain permission directly from the copyright holder.

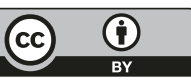

